\title{
DISTRIBUTION OF CRAYFISH IN SALZBURG, AUSTRIA
}

\author{
R.A. PATZNER, S. LANGMAIER, S. SCHACHERL, A. STRASSER, D. ZICK
}

Organismic Biology, University of Salzburg, Hellbrunnerstrasse 34, A-5020 Salzburg, Austria. E-Mail: robert.patzner@sbg.ac.at

Reçu le 4 novembre 2004

Accepté le 23 décembre 2004

Received November 4, 2004

Accepted December 23, 2004

\begin{abstract}
Mapping of crayfish populations in the province of Salzburg was carried out in the years 2002 and 2003. Five crayfish species were found, two of them native: Astacus astacus and Austropotamobius torrentium, and three foreign: Astacus leptodactylus, Pacifastacus leniusculus and Orconectes limosus. In former times the first two species were widely distributed especially in the northern part of the province. Today Astacus astacus is only found in (artificial) ponds and in one lake and its outlet. Austropotamobius torrentium is found in several small rivers, especially in the pre-alpine region. Astacus leptodactylus is found in three lakes connected to each other. Pacifastacus leniusculus is the most common crayfish species and widely distributed in rivers, ponds and lakes. Orconectes limosus is found in two lakes.
\end{abstract}

Key-words: Salzburg, Austria, crayfish, mapping, biogeography.

\section{DISTRIBUTION DES ÉCREVISSES DANS LA PROVINCE DE SALZBOURG, AUTRICHE}

\section{RÉSUMÉ}

La cartographie des populations d'écrevisses dans les environs de Salzbourg a été faite en 2002 et 2003. On a trouvé cinq espèces d'écrevisses. Deux sont natives: Astacus astacus et Austropotamobius torrentium, et trois sont étrangères: Astacus leptodactylus, Pacifastacus leniusculus et Orconectes limosus. Autrefois, les deux premières espèces était réparties dans le Nord. Maintenant on a trouvé Astacus astacus seulement dans des étangs (artificiels) et dans un lac et son écoulement. On a trouvé Austropotamobius torrentium dans différents ruisseaux, plus spécialement dans la région préalpine. Astacus leptodactylus a été trouvée dans trois lacs communicants. Pacifastacus leniusculus est l'espèce d'écrevisse la plus répandue et elle est déjà présente dans les ruisseaux, étangs et lacs. Orconectes limosus est présente dans deux lacs.

Mots-clés: Salzbourg, Autriche, écrevisse, description cartographique, biogéographie.

\section{INTRODUCTION}

Two species of crayfish are native to the province of Salzburg, Astacus astacus, the noble crayfish and Austropotamobius torrentium, the stone crayfish. In former times both were widely distributed in the northern part of Salzburg. We know of several relatively large 
populations of the noble crayfish in other areas, e.g. in lake Zellersee. Little is known about the past distribution of the stone crayfish because of its low economic value (HOFMANN, 1971).

Records of the use of crayfish for economic purposes in Salzburg go back as far as the $15^{\text {th }}$ century (FREUDELSBERGER, 1921). In the fishery statutes from the year 1600 the minimum length for crayfish allowed to be caught and the sentence for illegal catching were regulated. The same statutes declared that every year 15,000 individuals of noble crayfish from lake Zellersee had to be delivered to the archbishop of Salzburg (ZILLNER, 1865). These statutes were strictly policed up to 1803 when the archbishopric came to an end. In the late $19^{\text {th }}$ and the early $20^{\text {th }}$ century the crayfish plague was introduced into Central Europe. By 1950 most crayfish populations in Austria had been killed by the disease. To compensate for these losses the American crayfish Pacifastacus leniusculus, the signal crayfish, and Orconectes limosus, the spinycheek crayfish, were imported into Salzburg. In the years 1970 and 1971 the signal crayfish was brought from the Sierra Nevada to a pond in Hinterthal (Pinzgau) and to lake Fuschlsee (SPITZY, 1971). This caused the deadly crayfish plague to be spread further. Another reason for the decrease of the native crayfish was the poor condition of the waters. Rivers were regulated and waters polluted.

The past distribution of crayfish in Salzburg until the year 1997 is presented by PATZNER (1998). The fisheries map by KOLLMANN (1900) and the publications by FREUDELSBERGER $(1917,1921,1936,1937)$ provided a first insight. KOTSCHY (1979) reports from the Pinzgau, EXNER (1996) from the Lungau. WINTERSTEIGER (1985a, 1985b) summarizes basically the distribution of crayfish in Salzburg until 1983. Recent investigations were carried out by PATZNER (1999, 2001), RITTSTEIGER (2001), SCHACHERL (2003) and SCHACHERL and PATZNER (2003a, 2003b).

In the years 2002 and 2003, crayfish were mapped for the province of Salzburg by the Institute of Zoology (now Department of Organismic Biology) of the University of Salzburg, supported by the local government of Salzburg together with the fisheries association and the Austrian Ministry of Agriculture, Forestry, Environment and Water Management.

\section{MATERIAL AND METHODS}

From the middle of 2002 until October 2003 more than 1,000 locations were examined. At 351 of these crayfish were observed. Small rivers and littorals of standing waters were mainly inspected during the late evening using strong torches. Crayfish were collected by hand. In larger waters, traps from Finland were used with bait of liver from pig, cattle or chicken. In some locations material was provided by local fisherman (caught by hand and net). Waters were classified according to NOWOTNY and HINTERSTOISSER (1994). The altitudinal range of sampling positions was divided into 11 steps (Table 1). Crayfish species were identified and classified according to type of sample (living - skin - dead animal or parts of an animal) and abundance (rare, moderately frequent, frequent, very frequent).

From several locations, crayfish were kept as proofs. Animals were killed by deep freezing and fixed in alcohol so as to allow later genetic investigation. The conserved material is stored in the collection of the museum "Haus der Natur" in Salzburg.

All data were transferred to a MS-Access database. For analysis and cartographic representation the online information system BioMapper (@ BIOGIS CONSULTING, Paul SCHREILECHNER, Salzburg) was used. It is based on the desktop GIS programme ArcView by ESRI (PATZNER, 2001). 


\section{Table I}

Steps of altitude.

\section{Tableau I}

\section{Paliers d'altitude.}

\begin{tabular}{|c|l|}
\hline Steps & Altitude in meters \\
\hline 1 & 350 to $400 \mathrm{~m}$ \\
\hline 2 & 400 to $450 \mathrm{~m}$ \\
\hline 3 & 450 to $500 \mathrm{~m}$ \\
\hline 4 & 500 to $550 \mathrm{~m}$ \\
\hline 5 & 550 to $600 \mathrm{~m}$ \\
\hline 6 & 600 to $700 \mathrm{~m}$ \\
\hline 7 & 700 to $800 \mathrm{~m}$ \\
\hline 8 & 800 to $900 \mathrm{~m}$ \\
\hline 9 & 900 to $1,000 \mathrm{~m}$ \\
\hline 10 & 1,000 to $1,500 \mathrm{~m}$ \\
\hline 11 & 1,500 to $2,000 \mathrm{~m}$ \\
\hline
\end{tabular}

\section{RESULTS}

Five species of crayfish were found in the province of Salzburg (Figure 1), 2 of them are native, 3 introduced.

\section{Astacus astacus (LINNAEUS, 1758), noble crayfish (Figure 1)}

Is native to Salzburg. Twenty populations were found in the following types of biotope: natural pond, artificial pond, denaturalized pond, marshy lake and low-mountain river of morphological class 1 (only one lake outlet); preferred biotope: natural pond (52\%) (Tables II, III). Many of these waters are man-made and the noble crayfish were introduced into them. Altitude distribution ranges from step $3(450-500 \mathrm{~m})$ to step $11(1,500-2,000 \mathrm{~m})$, preferred altitudes at step 7 (700-800 m), and highest altitude of occurrence: lake Prebersee (Lungau, 1,514 m). The noble crayfish is listed as one of the critically endangered animals in the Red List for Austria (PRETZMANN, 1994).

\section{Austropotamobius torrentium (SCHRANK, 1803), stone crayfish (Figure 1)}

Is also native to Salzburg. Thirty populations were found in the following types of biotope: low-mountain river of morphological classes 1 and 2, lowland river of all morphological classes; preferred biotope: low-mountain river class 1 (57\%) (Tables II, III). Altitudinal distribution ranges between step 2 (400-450 m) and step 8 (800-900 m), mainly at step $6(600-700 \mathrm{~m})$, highest altitude of occurrence: Lienbach (Tennengau, $870 \mathrm{~m})$. The stone crayfish is listed among the strongly endangered animals in the Red List for Austria (PRETZMANN, 1994).

\section{Astacus leptodactylus (ESCHSCHOLZ, 1823), narrow-clawed crayfish (Figure 1)}

Was first imported to lake Zellersee in 1891, but failed to settle permanently. There were many attempts to establish the narrow-clawed crayfish in Salzburg. The only populations now left are found in lake Mattsee, lake Obertrumersee and lake Grabensee, all in the far north of the province. During mapping 4 populations were found in the following types of biotope: mesotrophic lake, eutrophic lake, lowland river of morphological class 1; 


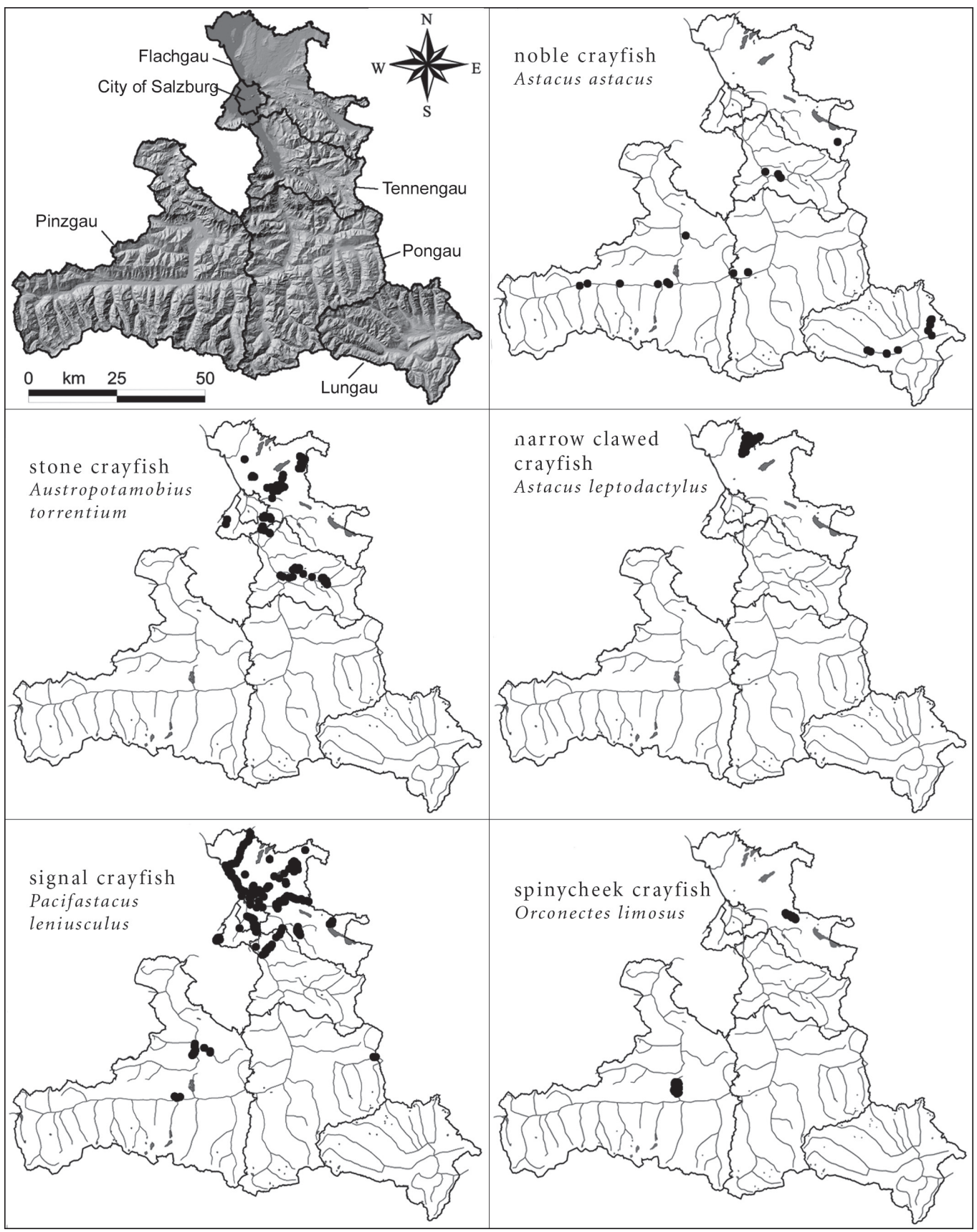

\section{Figure 1}

Topographic map showing districts ("Gaue") and maps of distribution of crayfish species in the province of Salzburg.

\section{Figure 1}

Carte topographique avec arrondissements ("Gaue") et cartes d'espèces d'écrevisses dans la province de Salzbourg.

preferred biotope: mesotrophic lake (77\%) (Table II, III). Altitudinal distribution exclusively at step 4 (500-550 m). Highest altitude of occurrence: above-mentioned lakes and one inlet (Flachgau, $503 \mathrm{~m}$ ). As the narrow-clawed crayfish is an introduced species it is not included in the Red List for Austria (PRETZMANN, 1994). 


\section{Table II}

Number of populations found during mapping, distributed after districts ("Gaue") and type of water (standing, running).

Tableau II

Nombre de populations trouvées, réparties par districts ("Gaue ») et type d'eaux (stagnantes et courantes).

\begin{tabular}{|c|c|c|c|c|c|c|}
\hline & & $\begin{array}{l}\text { Astacus } \\
\text { astacus }\end{array}$ & $\begin{array}{c}\text { Austropotamobius } \\
\text { torrentium }\end{array}$ & $\begin{array}{c}\text { Astacus } \\
\text { leptodactylus }\end{array}$ & $\begin{array}{l}\text { Pacifastacus } \\
\text { leniusculus }\end{array}$ & $\begin{array}{c}\text { Orconectes } \\
\text { limosus }\end{array}$ \\
\hline \multirow{2}{*}{$\begin{array}{l}\text { City of } \\
\text { Salzburg }\end{array}$} & standing & - & - & - & 2 & - \\
\hline & running & - & - & - & 9 & - \\
\hline \multirow[t]{2}{*}{ Flachgau } & standing & 1 & - & 3 & 4 & 1 \\
\hline & running & - & 20 & 1 & 23 & - \\
\hline \multirow[t]{2}{*}{ Tennengau } & standing & 4 & - & - & 2 & - \\
\hline & running & - & 10 & - & 1 & - \\
\hline \multirow[t]{2}{*}{ Pongau } & standing & 2 & - & - & - & - \\
\hline & running & - & - & - & 1 & - \\
\hline \multirow[t]{2}{*}{ Pinzgau } & standing & 7 & - & - & 5 & 1 \\
\hline & running & - & - & - & 4 & - \\
\hline \multirow[t]{2}{*}{ Lungau } & standing & 5 & - & - & - & - \\
\hline & running & 1 & - & - & - & - \\
\hline Total & & 20 & 30 & 4 & 51 & 2 \\
\hline
\end{tabular}

\section{Pacifastacus leniusculus (DANA, 1852), signal crayfish (Figure 1)}

Was first brought to Salzburg in 1970 (see "Introduction"). During mapping, 51 populations were found in the following types of biotope: oligotrophic and calcareous lake, mesotrophic lake, eutrophic lake, natural pond, artificial pond, denaturalized pond, reservoir, standing waters of flood plains, marshy lake, lowland river classes 1, 2, and 3, low-mountain river classes 1 and 2; preferred biotope: low-mountain river class $2(32 \%)$ (Tables II, III). Altitude distribution ranges between step 1 (350-400 m) and step 8 (800$900 \mathrm{~m})$, mainly at steps 4 and $5(500-600 \mathrm{~m})$, highest altitude of occurrence: Mandlinger Moorteich (Pongau, $810 \mathrm{~m}$ ). As the signal crayfish is also an introduced species it is not included in the Red List for Austria (PRETZMANN, 1994).

\section{Orconectes limosus (RAFINESQUE, 1817), spinycheek crayfish (Figure 1)}

Was also brought to Salzburg in 1970 (SPITZY, 1973). During mapping 2 populations were found, one in lake Fuschlsee, the other in lake Zellersee (biotope types: oligotrophic and calcareous lake, oligotrophic and not calcareous lake) (Tables II, III). Altitudinal distribution lies between steps 6 (600-700 m) and 7 (700-800 m). Highest altitude of occurrence: $750 \mathrm{~m}$ (lake Zellersee, Pinzgau). As the spinycheek crayfish is also an introduced species it is not included in the Red List for Austria (PRETZMANN, 1994).

\section{Procambarus clarkii (GIRARD, 1852), red swamp crayfish}

Some years ago this species was observed in two rivers in the city of Salzburg (Aubach in Aigen und Alterbach in Izling) (personal communication by JERSABEK). During mapping in 2002 and 2003 it could not be found again. 
Table III

Distribution of crayfish in different types of biotopes in the Province of Salzburg (declaration in percent). Types of biotopes after NOWOTNY and HINTERSTOISSER (1994). * Classes of ecomorphology, not water quality.

\section{Tableau III}

Distribution d'écrevisses dans différents types de biotopes dans la province de Salzbourg (déclaration en pourcentage). Types de biotopes d'après NOWOTNY et HINTERSTOISSER (1994). Classes d'écomorphologie, pas de qualité d'eau.

\begin{tabular}{|c|c|c|c|c|c|c|}
\hline & Type of water & $\begin{array}{l}\text { Astacus } \\
\text { astacus }\end{array}$ & $\begin{array}{c}\text { Austropotamobius } \\
\text { torrentium }\end{array}$ & $\begin{array}{c}\text { Astacus } \\
\text { leptodactylus }\end{array}$ & $\begin{array}{l}\text { Pacifastacus } \\
\text { leniusculus }\end{array}$ & $\begin{array}{l}\text { Orconectes } \\
\text { limosus }\end{array}$ \\
\hline \multirow{10}{*}{ 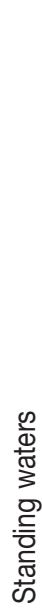 } & $\begin{array}{l}\text { lake, oligotrophic and not } \\
\text { calcareous }\end{array}$ & - & - & - & - & 50 \\
\hline & $\begin{array}{l}\text { lake, oligotrophic and } \\
\text { calcareous }\end{array}$ & - & - & - & 5 & 50 \\
\hline & lake, mesotrophic & - & - & 77 & 2 & - \\
\hline & lake, eutrophic & - & - & 19 & - & - \\
\hline & reservoir & - & - & - & 2 & - \\
\hline & natural pond & 52 & - & - & 1 & - \\
\hline & artificial pond & 8 & - & - & 3 & - \\
\hline & denaturised pond & 12 & - & - & 3 & - \\
\hline & still waters of flood plains & - & - & - & 3 & - \\
\hline & marshy lake & 24 & - & - & 2 & - \\
\hline \multirow{6}{*}{ 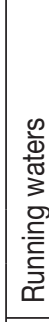 } & mid-mountain river, class $1^{*}$ & 4 & 57 & - & 5 & - \\
\hline & mid-mountain river, class $2^{*}$ & - & 5 & - & 8 & - \\
\hline & lowland river, class $1^{*}$ & - & 19 & 4 & 29 & - \\
\hline & lowland river, class $2^{*}$ & - & 19 & - & 32 & - \\
\hline & lowland river, class $3^{*}$ & - & 1,5 & - & 5 & - \\
\hline & lowland river, class $4^{*}$ & - & 1,5 & - & - & - \\
\hline \multicolumn{2}{|c|}{ Total } & 100 & 100 & 100 & 100 & 100 \\
\hline
\end{tabular}

\section{DISCUSSION AND CONCLUSSION}

In former times the noble crayfish was frequently found in all parts of the province, especially in the Flachgau (WINTERSTEIGER, 1985a, 1985b). Remarkable is the occurrence of a large population in lake Prebersee at an altitude of more than 1,500 m. The mapping has shown that with the exception of the outflow of lake Prebersee, no populations exist now in running waters. Main reasons are the crayfish plague and water pollution. Recently water quality has improved in all rivers and lakes. This provides the opportunity to reestablish former populations of the noble crayfish. However, care has to be taken to ensure that the water has no connection with water containing signal crayfish or spinycheek crayfish, since these are in most cases infected with the crayfish plague (OIDTMAN and HOFFMANN, 1998; OIDTMANN et al., 2002). It also has to been taken in consideration that in many fish farms signal crayfish are cultivated (BOHL et al., 2001). In lake Hintersee a good population of noble crayfish was destroyed by the introduction of some signal crayfish (RITTSTEIGER, 2001). However, in some lakes of Finland both species live in sympatry; indicating that the $P$. leniusculus population must be plague-free. Nevertheless 
the catches of the noble crayfish decreased and the catches of signal crayfish increased. (WESTMAN and SAVOLAINEN, 2001). In 2004 a project was started in Salzburg to check if populations of signal crayfish are infected by the crayfish plague or not.

Several populations of stone crayfish survive in small rivers of Flachgau and Tennengau but the species has vanished from Pongau and Lungau. Most probably it never existed in Pinzgau (personal communication by KOTSCHY). In Salzburg this species was only found in running waters.

The introduced narrow-clawed crayfish is only found in a group of lakes in the north of the province of Salzburg. Even though this species is not infected with the crayfish plague it has displaced the noble crayfish from these lakes. A great problem is the presence of the signal crayfish in many running waters, especially in the Flachgau. It is not possible to remove this species completely from a water to make it available for native crayfish (KELLER, 2002). The same has to be said of the spinycheek crayfish and the red swamp crayfish. However, these species are not so problematic in Salzburg at the time of writing (see "results").

In August 2002, mapping and collecting of crayfish was not possible because of severe flooding. The strong water movement affected many populations. Some of them were severely reduced; others completely destroyed (personal communication by fishermen). As many individuals were forced to drift one may assume that all running waters containing signal crayfish are now infected with the crayfish plague as far as the outflow. The summer of 2003 was extremely dry. Several small rivers containing stone crayfish fell dry and some populations became extinct.

\section{ACKNOWLEDGEMENTS}

Financial support was provided by the local government of Salzburg ("Amt der Salzburger Landesregierung"), the Austrian Ministry of Agriculture, Forestry, Environment and Water Management and the "Naturschutzbund" in Salzburg. Valuable informations were given by Mag. Daniela Latzer, Dr. Klaus Kotschy, Walter Dorfer (†), Ulrike and Nicola Bayrhammer, Erhard Schwarz, Ernst Rittsteiger, Stefan Magg, Erich Hofer, Gerald Hochwimmer and several others. Help by collection the material was given by Mag. Stefan Achleitner, Hannes Ackerl, Roland Kaiser and Markus Keuschnig.

\section{REFERENCES}

BOHL E., KELLER M., OIDTMAN B., 2001. Flußkrebse in Bayern. Landesfischereiverband Bayern e.V. \& Bayerisches Landesamt für Wasserwirtschaft.

EXNER W., 1996. Der historische Fischbestand des Lungaues. Salzburgs Fischerei, 27, 42-43.

FREUDLSPERGER H., 1917. Fischereiverhältnisse auf dem Zellersee im Pinzgau, 1799. Österr. Fischerei Ztg., 14, 70-72.

FREUDLSPERGER H., 1921. Die Fischerei im Erzstift Salzburg und ihre Lehren. Österr. Fischerei Ztg., 18, 89-124.

FREUDLSPERGER H., 1936. Kurze Fischereigeschichte des Erzstiftes Salzburg. I. Teil. Mitt. Ges. Sbg. Landeskunde, 76, 81-128.

FREUDLSPERGER H., 1937. Kurze Fischereigeschichte des Erzstiftes Salzburg. II. Teil. Mitt. Ges. Sbg. Landeskunde, 77, 145-175.

HOFMANN J., 1971. Die Flusskrebse: Biologie, Haltung und wirtschaftliche Bedeutung. P. Parey, Hamburg. 102 p. 
KELLER M., 2002. Strategische Überlegungen und Vorgehensweisen zum Erhalt heimischer und zur Bekämpfung gebietsfremder Flusskrebse. In: Internationale Flusskrebstagung in Blieskastel/Saarland (Tagungsband). Ministerium für Umwelt, FV Saar e.V., Saarpfalz-Kreis und Stadt Blieskastel.

KOLLMANN J., 1900. Fischereikarte und Fischereikataster des Landes Salzburg, Stand 1898.

KOTSCHY K., 1979. Edelkrebsvorkommen im Pinzgau. Österr. Fischerei, 11, 238.

NOWOTNY, G., HINTERSTOISSER H., 1994. Biotopkartierung Salzburg Kartierungsanleitung. Amt der Salzburger Landesregierung, Referat 13/02.

OIDTMANN B., HOFFMANN R.W., 1998. Die Krebspest. Stapfia, 58, 187-196.

OIDTMANN B., HEITZ E,. ROGERS D., HOFFMANN R., 2002. Transmission of crayfish plague. Dis. Aquat. Org., 52, 159 - 167.

PATZNER R.A., 1998. Flußkrebse im Bundesland Salzburg. Stapfia, 58, 67-76.

PATZNER R.A., 1999. Flußkrebse im Bundesland Salzburg. Salzburgs Fischerei, 30 (2), 44-46.

PATZNER R.A., 2001. Kartierung von Flusskrebsen im Bundesland Salzburg. Sauteria, 11, 223-229.

PRETZMANN G., 1994. Rote Liste der Zehnfüßigen Krebse (Decapoda) und der Schwebegarnelen (Mysidacea) Österreichs. In: GEPP, J. (ed.), Rote Liste gefährdeter Tiere Österreichs, 279-282. Styria Medienservic, Graz.

RITTSTEIGER E., 2001. Gefährdungsursache Signalkrebs. - Fallbeispiel Hintersee. Crayfish meeting Kartause Gaming, Austria, 16-18.

SCHACHERL S., 2003. Untersuchungen an zwei Teichpopulationen des Edelkrebses Astacus astacus (Linnaeus 1758). Master thesis, University of Salzburg.

SCHACHERL S., PATZNER R.A., 2003a. Krebse in unseren Gewässern (Teil I). Salzburgs Fischerei, 34 (2), 18-22.

SCHACHERL S., PATZNER R.A., 2003b. Krebse in unseren Gewässern (Teil II). Salzburgs Fischerei, 34 (2), 16-20.

SPITZY R., 1971. Resistente amerikanische Krebse ersetzen die europäischen, der Krebspest erliegenden Astaciden. Salzburgs Fischerei, 2, 18-25.

SPITZY R., 1973. Crayfish in Austria, history and actual situation. In: ABRAHAMSSON S. (ed.), Freshwater crayfish. First International Symposium on Freshwater Crayfish, Austria, 1972, 135-150, Studentlitteratur, Lund.

WESTMAN K, SAVOLAINEN R., 2001. Long term study of competition between two co-occurring crayfish species, the native Astacus astacus L. and the introduced Pacifastacus leniusculus Dana, in a Finnish lake. Bull. Fr. Pech. Piscic., 361, 613627.

WINTERSTEIGER M., 1985a. Studie zur gegenwärtigen Verbreitung der Flußkrebse in Österreich und zu den Veränderungen ihrer Verbreitung seit dem Ende des 19. Jahrhunderts. Ergebnisse limnologischer und astacologischer Untersuchungen an Krebsgewässern und Krebsbeständen. Ph.D. thesis, University of Salzburg.

WINTERSTEIGER M., 1985b. Zur Besiedlungsgeschichte und Verbreitung der Flußkrebse im Land Salzburg. Österr. Fischerei, 38, 220-233.

ZILLNER F.V., 1865. Salzburgische Fischer- und Seenordnungen. Mitt. der Ges. f. Sbg. Landeskunde, 5, 80-104. 